\title{
DIABETIC FOOT ULCER TREATMENT POST AUTOAMPUTATION DIGITI PEDIS SINISTRA: CASE STUDY
}

\author{
Nur Azizah', Irfani Intan², Dwiyana Tulak ${ }^{3}$, Muh. Adhan Kurniawan4, Titi Iswanti \\ Afelya $^{5}$ \\ 1,2,3,4,5 Program Studi Imu Keperawatan, Fakultas Keperawatan Universitas Hasanuddin, Makassar \\ e-mail : azizahtamsil@gmail.com
}

\begin{abstract}
Introduction: Diabetes mellitus is a chronic disease that occurs when the pancreas does not produce enough insulin or when the body cannot effectively use the insulin it produces. According to the International Diabetes Federation, there are 425 million people suffering from diabetes in the world and will increase by 629 million in 2045 . There were more than $10,276,100$ cases of diabetes in Indonesia in 2017 and ranked 6 out of the top 10 countries for the number of diabetics. Diabetics have an increased risk of a number of serious health problems, one of which is the cause of foot amputation. Amputation occurs 15 times more often in diabetics than non-diabetics. Effective and comprehensive foot care can prevent the risk of ulcer becoming amputation. This study aims to provide an overview of the treatment process and the development of wounds for five weeks of treatment. Method: This study was conducted prospectively using a prospective cohort study by providing wound care to one respondent with diabetic foot ulcer for five weeks at Griya Afiat Wound Care Clinic, Makassar. Wounds were assessed using the Wound Nursing Care format from Griya Afiat Clinic. Result: the first and second week is inflammatory phase, the third to fifth week is proliferation process There is a change in the size of each wound and increasing the process of granulation and epithelialization every week of treatment until the fifth week of treatment, the wound begins to increase epithelialization and changes in wound size, especially in undermining. Conclusion: During the five weeks of treatment, the wound healing process has developed well. The wound has no potential for amputation if the wound care process is still balanced with the selection of appropriate dressings and patient compliance in performing wound care. Other factors that inhibit the wound healing process need to be known.
\end{abstract}

Keywords : Diabetes Mellitus, Diabetic Foot Ulcer, Post Autoamputation.

\section{PENDAHULUAN}

Diabetes Melitus (DM) adalah penyakit kronis serius yang terjadi ketika pankreas tidak menghasilkan cukup insulin (hormon yang mengatur glukosa darah), atau ketika tubuh tidak dapat secara efektif menggunakan insulin yang dihasilkannya (World Health Organization, 2016).

Menurut International Diabetes Federation, terdapat 425 juta orang yang menderita diabetes di dunia dan akan meningkat sebesar 629 juta orang pada tahun 2045. Indonesia terdapat lebih dari 10.276.100 kasus diabetes pada tahun 2017 dari total populasi dewasa sebesar 166.531.000 yang berarti terdapat prevalensi penderita diabetes sebesar 6,7\% dan menduduki peringkat 6 dari 10 negara teratas untuk jumlah penderita diabetes (International Diabetes Federation, 2017).

Penderita diabetes memiliki peningkatan risiko sejumlah masalah kesehatan yang serius. Kadar glukosa darah yang tinggi secara konsisten dapat menyebabkan penyakit serius 
yang mempengaruhi jantung dan pembuluh darah, mata, ginjal, saraf dan gigi. Selain itu, penderita diabetes juga memiliki risiko lebih tinggi terkena infeksi. Di hampir semua negara berpenghasilan tinggi, diabetes adalah penyebab utama penyakit kardiovaskular, kebutaan, gagal ginjal, dan amputasi ekstremitas bawah (IDF, 2017).

Ulkus kaki dan amputasi merupakan konsekuensi dari neuropati diabetik dan/atau penyakit arteri perifer yang biasa terjadi dan merupakan penyebab utama morbiditas dan mortalitas pada penderita diabetes. Pengenalan dini dan perawatan pasien dengan diabetes dan kaki beresiko untuk ulkus dan amputasi dapat menunda atau mencegah hasil yang lebih merugikan (American Diabetes Association, 2018). Pada penderita DM banyak yang mengeluhkan terjadinya ulkus diabetik sehingga diabetes mellitus menjadi penyebab terjadinya amputasi kaki pada penderita DM. Amputasi terjadi 15 kali lebih sering pada penderita diabetes daripada nondiabetes. Pada tahun 2032, seiring dengan peningkatan jumlah penyandang diabetes di dunia, terjadi peningkatan kaki diabetik (Perkumpulan Endokrinologi Indonesia, 2015).

Tindakan pencegahan menurut Ar Ardi, Damayanti, \& Sudirman (2014), kepatuhan pasien dalam perawatan atau mengatur dirinya untuk mengontrol kadar glukosa darah melalui kedisiplinan diet, melakukan pencegahan luka, serta perawatan kaki seperti yang telah disarankan oleh tenaga kesehatan. Perawatan kaki yang dilakukan secara efektif dapat mencegah resiko ulkus menjadi amputasi. Dengan dilakukan manajemen yang komprehensif, sebagian besar amputasi yang berkaitan dengan diabetes dapat dicegah. Bahkan ketika amputasi berlangsung, kaki yang tersisa dan kehidupan orang tersebut dapat diselamatkan dengan perawatan tindak lanjut yang baik.

Dillihat dari fenomena tersebut diharapkan dengan dilakukannya perawatan kaki diabetes yang optimal maka kasus amputasi dapat dicegah. Serta mampu meningkatkan kesejahteraan hidup bagi pasien dengan post amputasi. Tujuan dari laporan kasus ini adalah memberikan gambaran perawatan luka serta menilai proses perawatan dan perkembangan luka kaki diabetes pada pasien diabetes melitus selama lima minggu.

\section{METODE}

Penelitian ini merupakan jenis penelitian yang dilakukan secara prospektif dalam bentuk laporan kasus yang dimulai dari tanggal 10 September - 9 Oktober 2018 di klinik Perawatan Luka Griya Afiat, Gowa. Sampel yang diteliti sebanyak satu orang dengan kriteria luka kaki diabetes di daerah dorsal dan plantar kaki kanan.

Studi demografi dan pengkajian luka didapatkan melalui wawancara langsung kepada pasien dan keluarga dengan menggunakan format pengkajian dari Klinik Griya Afiat yang terdiri atas data demografi, status kesehatan, status diabetes, dan riwayat luka. Adapun evaluasi proses perawatan menggunakan Format Asuhan Keperawatan: Proses Perawatan dan Evaluasi Proses Penyembuhan Luka yang terdiri atas masalah luka, tujuan perawatan luka, dressing yang digunakan, penampilan klinis luka, ukuran luka, eksudat, kondisi kulit sekitar luka, nyeri, status infeksi, serta edema.

Perkembangan luka selama 5 minggu dinilai dengan bantuan mistar luka dan menggunakan pinset untuk mengukur kedalaman goa (undermining) sesuai dengan arah jarum jam (panjang $\mathrm{x}$ lebar $\mathrm{x}$ kedalaman) dan 
Dokumentasi luka menggunakan kamera ponsel berbasis OS Android dengan kapasitas minimal 8-13 MP.

\section{HASIL}

Tn. S berusia 77 tahun, suku makassar, dan beragama islam. Klien bekerja sebagai tukang becak, status pernikahan menikah dan pendidikan terakhir adalah sekolah dasar. Klien mengalami luka kaki diabetik pada kaki kiri. Tekanan darah 120/70 $\mathrm{mmHg}$, hasil pemeriksaan gula darah pada tanggal 6 september 2018 adalah $141 \mathrm{mg} / \mathrm{dl}$. IMT tidak didapat dilakukan pengukuran karena klien tidak mampu berdiri secara baik, klien mengkomsumsi obat oral diabetes 2 kali sehari dan antibiotik. Klien telah berhenti merokok sejak sakit.

Riwayat luka yang dialami disebabkan tusukan tulang ikan dan diperberat dengan aktivitas klien sebagai pengayuh becak. Klien diketahui menderita penyakit diabetes melitus saat mendapakan luka tersebut dan memeriksakan di rumah sakit. Klien pernah dirawat di RSUD. Syekh Yusuf pada bulan Juli tahun 2018. Klien direncanakan untuk amputasi jari kaki tengah yang mulai mengalami nekrotik tetapi klien menolak dan klien memilih keluar dari RS. Setelah 3 hari dirawat, klien keluar dan memutuskan untuk mendapat perawatan di Klinik Griya Afiat. Setelah dirawat, jari kaki tengah klien mengalami autoamputasi diikuti jari keempat dan kelima. Terdapat 8 bagian luka pada kaki kiri Tn. S, luka A berada pada bagian plantar hingga digitus III pedis sampai digitus $\mathrm{V}$ pedis dan memiliki undermining, luka B berada pada bagian plantar dibawah digitus I pedis, luka $\mathrm{C}$ berada pada bagian antara digitus I pedis dan digitus II pedis, luka $\mathrm{D}$ berada pada bagian dorsal, luka $\mathrm{E}$ dan $F$ berada pada bagian lateral, dan luka $\mathrm{G}$ dan $\mathrm{H}$ berada pada bagian medial. Menurut klasifikasi Wagner,
Luka klien berada pada derajat II yaitu ulkus dalam dan menembus tendon dan tulang.

\section{Perawatan Minggu Ke-1 (Senin, 10 September 2018)}

Pada minggu pertama perawatan luka, yang pertama dilakukan adalah membuka balutan lama kemudian mencuci luka dengan menggunakan air mineral dan sabun antiseptik dimulai dari arah luar kemudian ke dalam luka. Teknik membersihkan luka menggunakan metode irigasi untuk luka dengan undermining. Setelah dicuci, luka kemudian dikeringkan. Keadaan luka memiliki banyak undermining. Berdasarkan struktur lapisan kulit, luka berada pada full thickness yang melibatkan epidermis, dermis, lapisan lemak, fascia dan bahkan sampai ke tulang. Penampilan klinis lain ditemukan adanya slough/infeksi, disertai odor, kulit sekitar luka mengalami maserasi, serta edema. Dari masalah luka tersebut maka tujuan perawatannya adalah untuk menghilangkan/autolysis slough, menurunkan jumlah bakteri, mencegah perdarahan, mengotrol bau, melindungi kulit sekitar luka dan jaringan epitel. Teknik debridemen yang digunakan yaitu Conservatif Sharp Wound Debridement (CSWD) dan autolysis. Dressing yang digunakan pada perawatan luka yaitu hidrofobik dan salep zink sebagai dressing primer, kasa steril dan diaper sebagai balutan sekunder, serta kasa gulung sebagai balutan tersier. Untuk perawatan periwound digunkan salep zink. Adapun ukuran luka pada luka A yakni $11 \times 4.5 \times 2.4 \mathrm{~cm}^{3}$, luka B $2 \times 1 \times 3$ $\mathrm{cm}^{3}$, luka C $2.5 \times 1.2 \mathrm{~cm}^{2}$, Luka D $0.4 \mathrm{x}$ $0.3 \times 4.7 \mathrm{~cm}^{3}$, Luka E $2 \times 1.2 \times 9.7 \mathrm{~cm}^{3}$, Luka F $5 \times 2.5 \times 2 \mathrm{~cm}^{3}$, Luka G $2 \times 1.2$ x $7 \mathrm{~cm}^{3}$, Luka H 0.6 x 0.3 x $4 \mathrm{~cm}^{3}$. 


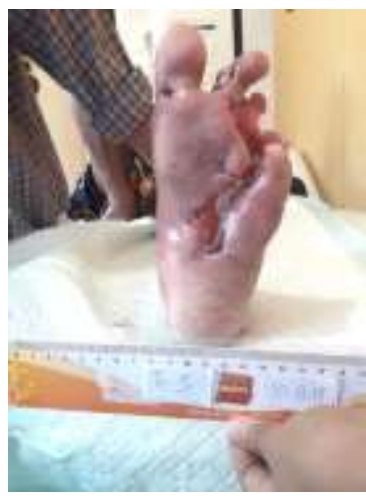

Gambar 1.1 Luas luka A pada perawatan minggu 1

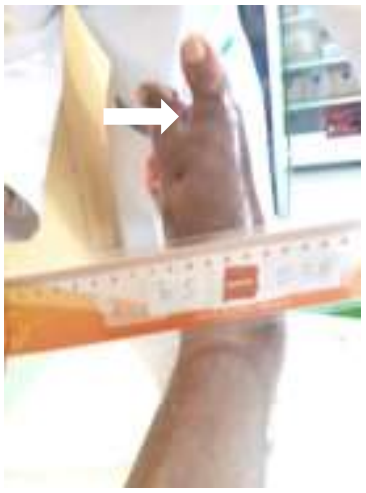

Gambar 1.3 Luas luka $\mathrm{C}$ pada perawatan minggu 1

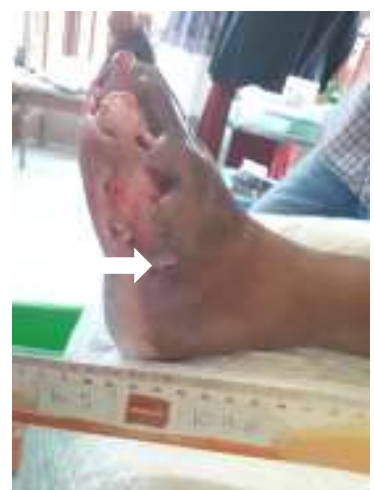

Gambar 1.5 Luas luka E pada perawatan minggu 1

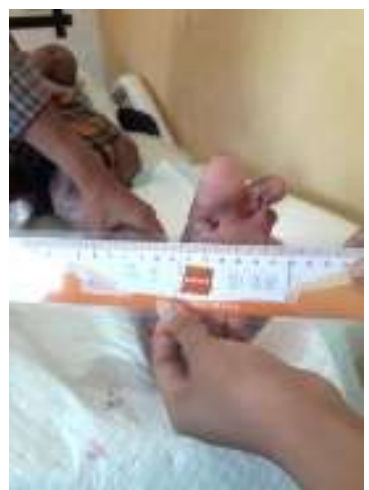

Gambar 1.2 Luas luka B pada perawatan minggu 1

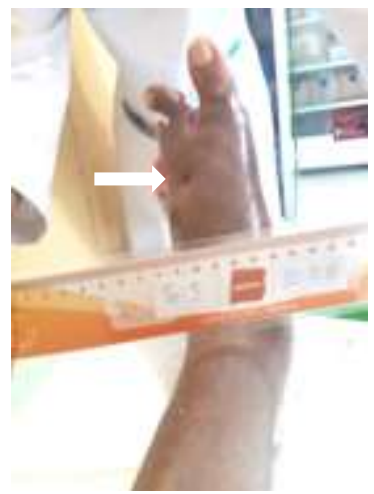

Gambar 1.4 Luas luka D pada perawatan minggu 1

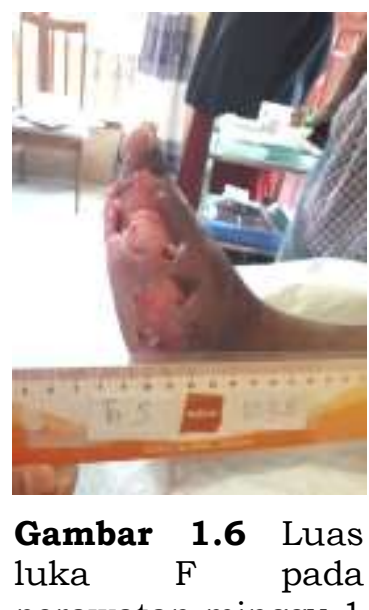
perawatan minggu 1
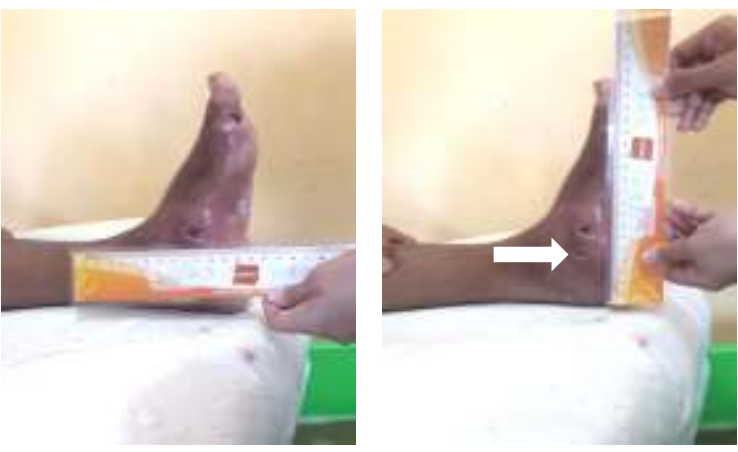

Gambar 1.7 Luas Gambar 1.8 Luas luka $G$ pada luka $H$ pada perawatan minggu 1 perawatan minggu 1

\section{Perawatan Minggu Ke-2 (Sabtu, 22 September 2018)}

Pada minggu kedua, Keadaan luka masih memiliki banyak undermining. Penampilan klinis lain ditemukan adanya slough/infeksi, disertai odor, kulit sekitar luka mengalami maserasi, serta edema. Ukuran luka pada beberapa luka mulai mengecil di akhir perawatan minggu ke-2 yaitu pada luka A yakni $9 \times 4 \times 1.1 \mathrm{~cm}^{3}$, luka B $2 \times 1 \mathrm{x}$ $2.5 \mathrm{~cm}^{3}$, Luka C $2.5 \times 1,2 \mathrm{~cm}^{2}$, Luka D $0.4 \times 0.3 \times 2 \mathrm{~cm}^{3}$, Luka E $2 \times 1.2 \times 5.6$ $\mathrm{cm}^{3}$, Luka F $5 \times 2.5 \times 1.8 \mathrm{~cm}^{3}$, Luka G $2 \times 1.2 \times 7 \mathrm{~cm}^{3}$, Luka $\mathrm{H} 0.6 \times 0.3 \times 2$ $\mathrm{cm}^{3}$

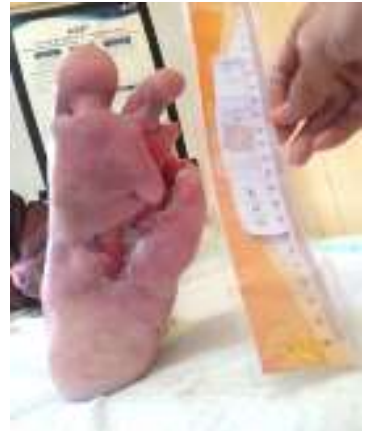

Gambar 2.1 Luas luka A pada perawatan minggu 2

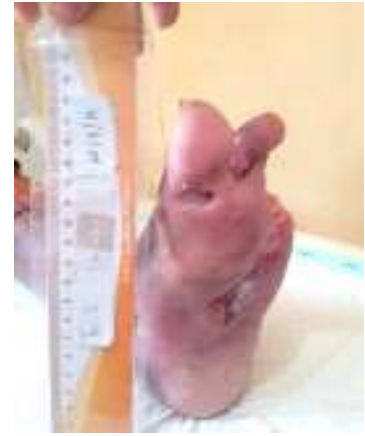

Gambar 2.2 Luas luka B pada perawatan minggu 2 

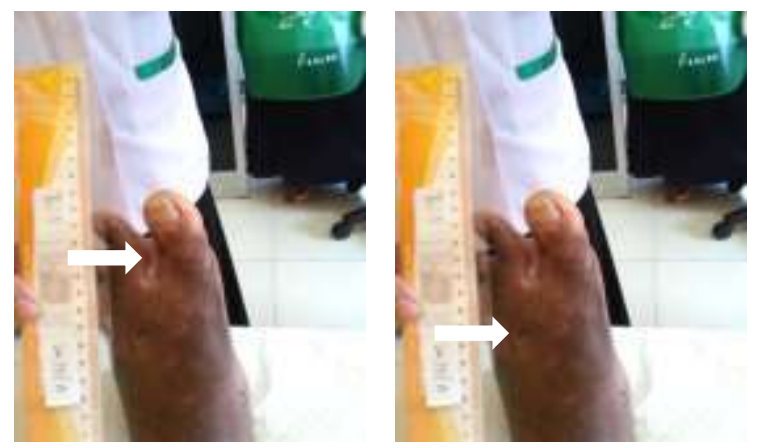

Gambar 2.3 Luas Gambar 2.4 Luas luka C pada luka D pada perawatan minggu 2 perawatan minggu 2

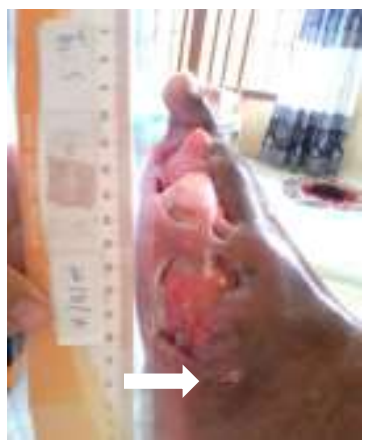

Gambar 2.5 Luas luka E pada perawatan minggu 2

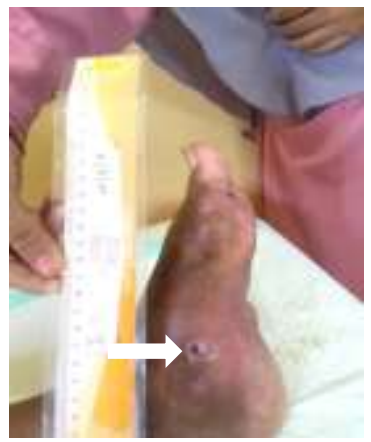

Gambar 2.7 Luas Gambar 2.8 Luas luka $\mathrm{G}$ pada luka $\mathrm{H}$ pada perawatan minggu 2 perawatan minggu 2

\section{Perawatan Minggu Ke-3 (Rabu, 26 September 2018)}

Proses perawatan minggu ketiga, masalah luka yang ditemukan yaitu: slough/infeksi, disertai odor, dan kulit sekitar luka mengalami maserasi. Keadaan luka telah mengalami peningkatan pengecilan ukuran luka

yaitu pada luka A yakni $9 \times 4 \times 1.1$ $\mathrm{cm}^{3}$, luka B $2 \times 1 \times 2 \mathrm{~cm}^{3}$, Luka C $2.5 \mathrm{x}$ $1.2 \mathrm{~cm}^{2}$, Luka D $0.4 \times 0.3 \times 2 \mathrm{~cm}^{3}$, Luka E $2 \times 1 \times 5.6 \mathrm{~cm}^{3}$, Luka F $4.8 \times$ $2.5 \times 1.8 \mathrm{~cm}^{3}$, Luka G $1.5 \times 1.2 \times 7$ $\mathrm{cm}^{3}$, Luka H $0.5 \times 0.3 \mathrm{~cm}^{2}$.
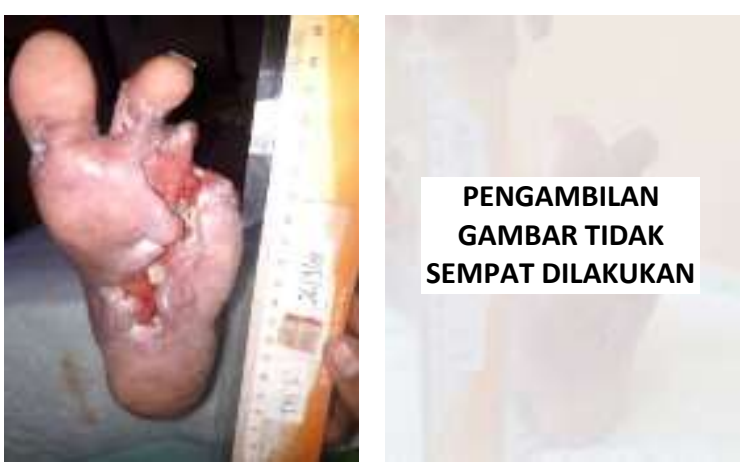

Gambar 3.1 Luas luka A pada perawatan minggu 3

Gambar 3.2 Luas luka B pada perawatan minggu 3
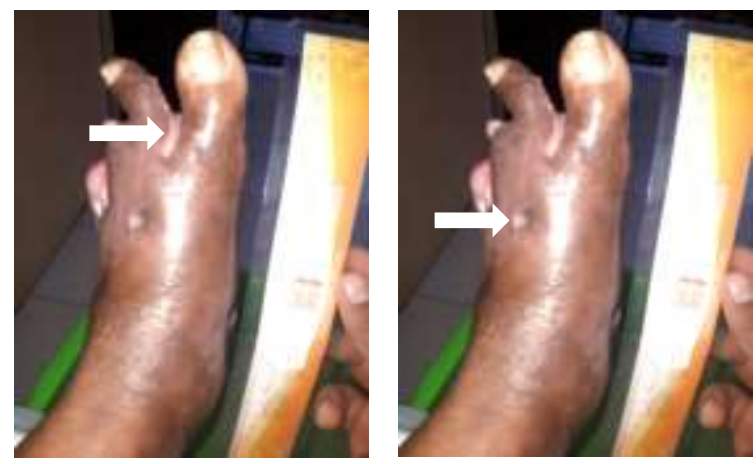

Gambar 3.3 Luas luka $\mathrm{C}$ pada perawatan minggu 3

Gambar 3.4 Luas luka D pada perawatan minggu 3

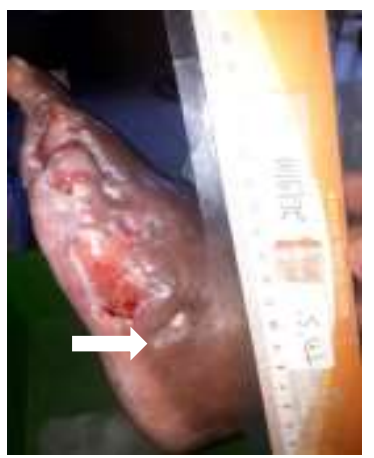

Gambar 3.5 Luas luka E pada perawatan minggu 3

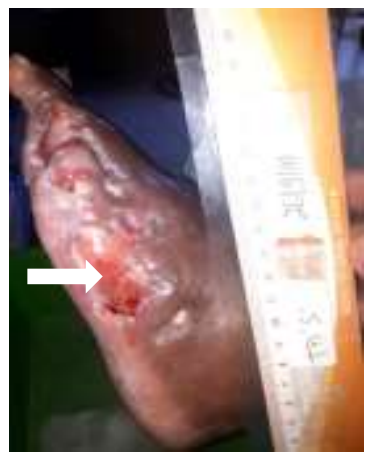

Gambar 3.6 Luas luka $F$ pada perawatan minggu 3 

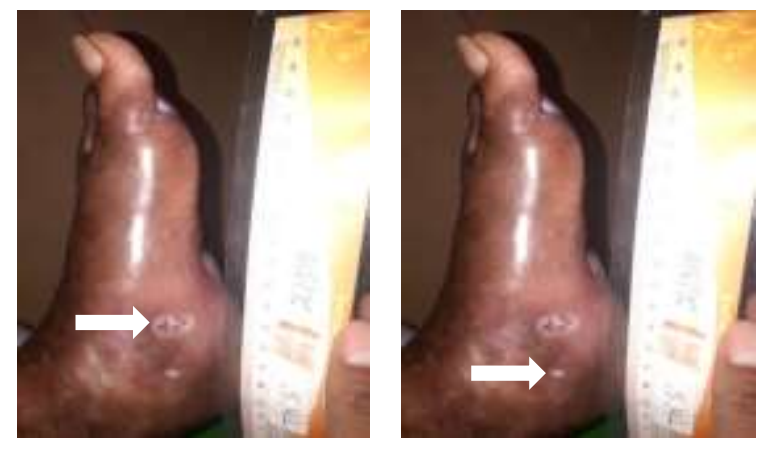

Gambar $\quad 3.7$ Luas luka $G$ pada perawatan minggu 3

Gambar 3.8 Luas luka $H$ pada perawatan minggu 3

\section{Perawatan Minggu Ke-4 (Jumat, 05 Oktober 2018)}

Proses perawatan pada minggu ke-4, keadaan luka mulai terdapat slough yang sedikit, namun masih berbau tidak sedap, dan mengalami maserasi. Beberapa luka mengalami peningkatan epitelisasi dan terdapat perubahan pada Luka B (Gambar 4.2), yaitu tidak disertai undermining. Ukuran luka A yakni $8 \times 2.5 \times 1.1 \mathrm{~cm}^{3}$, luka B $2 \times 1.8 \mathrm{~cm}^{3}$, Luka C $2 \times 1 \mathrm{~cm}^{2}$, Luka D $0.5 \times 0.5 \times 2 \mathrm{~cm}^{3}$, Luka E $1.7 \times$ $1 \times 6.8 \mathrm{~cm}^{3}$, Luka F $4.8 \times 2.5 \times 1 \mathrm{~cm}^{3}$, Luka G 1.5 × 1 x $7 \mathrm{~cm}^{3}$, Luka H 0.7 x $0.4 \times 1.5 \mathrm{~cm}^{3}$.

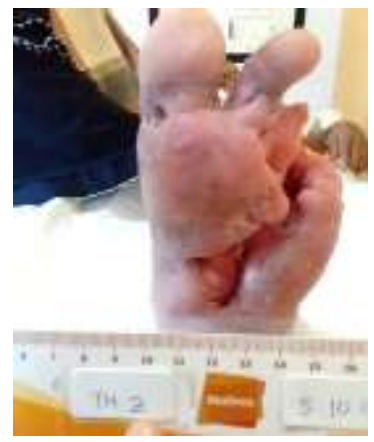

Gambar 4.1 Luas luka A pada perawatan minggu 4

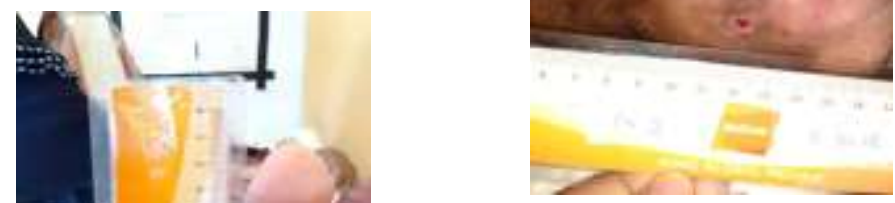
luka $G$ pada perawatan minggu 4
Gambar 4.7 Luas

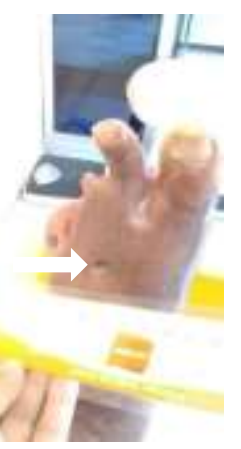

Gambar 4.3 Luas Gambar 4.4 Luas luka $\mathrm{C}$ pada luka $\mathrm{D}$ pada perawatan minggu 4 perawatan minggu 4
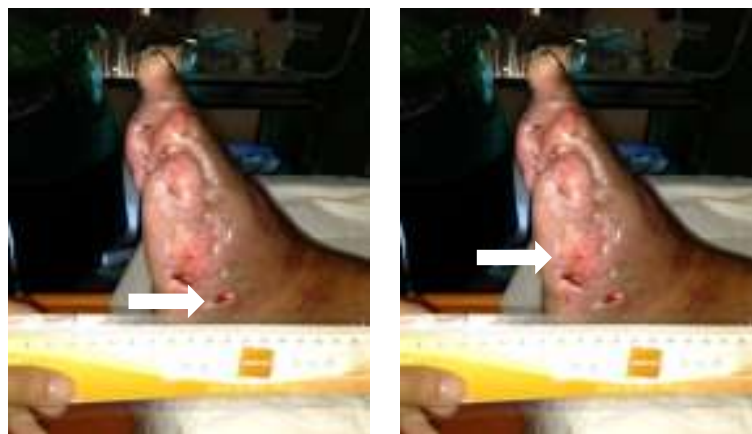

Gambar 4.5 Luas luka E pada perawatan minggu 4
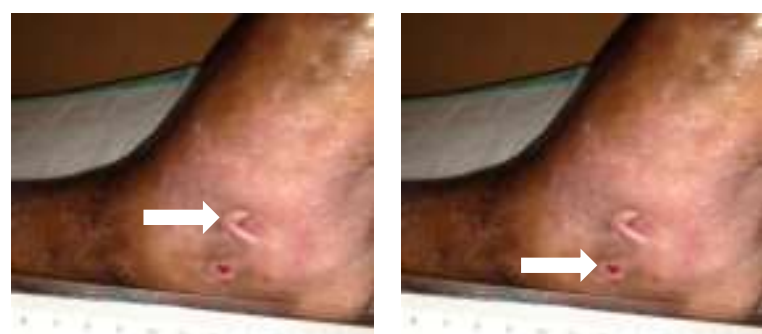

\section{Perawatan Minggu Ke-5 (Rabu,} 10 Oktober 2018)

Perawatan luka minggu kelima, keadaan luka mulai mengalami peningkatan epitelisasi dan mengalami perubahan ukuran luka terutama pada undermining. Untuk luka D memiliki penambahan ukuran panjang dan untuk mengeluarkan slough yang 
mengeras. Sedangkan luka $\mathrm{H}$ menunjukkan progress yang kurang baik karena undermining yang telah menutup dan menunjukkan proses epitelisasi kembali terbuka. Ukuran luka A yakni $8 \times 2 \times 1.5 \mathrm{~cm}^{3}$, luka B $2 \times$ $1.8 \mathrm{~cm}^{2}$, Luka C $2 \times 1 \mathrm{~cm}^{2}$, Luka D 0.7 x 0.5 × $3 \mathrm{~cm}^{3}$, Luka E $1.7 \times 0.7 \times 6.8$ $\mathrm{cm}^{3}$, Luka F $4.8 \times 3 \times 1 \mathrm{~cm}^{3}$, Luka G $1.5 \times 1 \times 6.5 \mathrm{~cm}^{3}$, Luka $\mathrm{H} 1.3 \times 0.3 \times 1$ $\mathrm{cm}^{3}$.

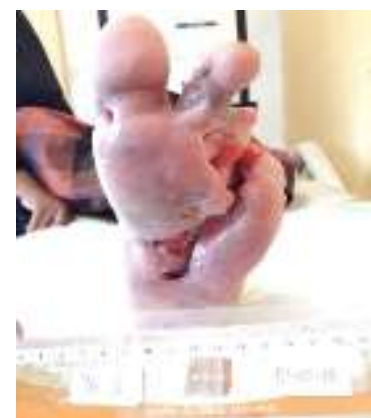

Gambar 5.1 Luas luka A pada perawatan minggu 5

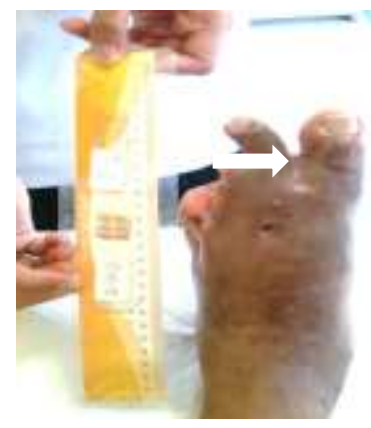

Gambar 5.3 Luas luka C pada perawatan minggu 5

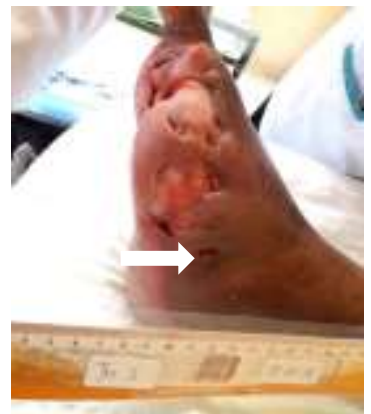

Gambar 5.5 Luas luka E pada perawatan minggu 5

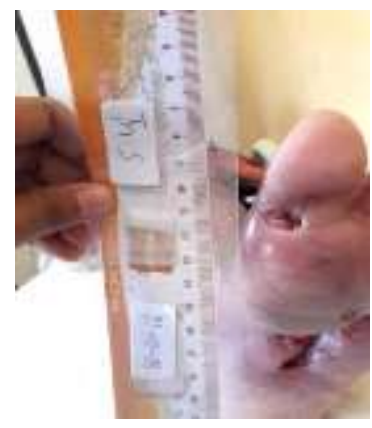

Gambar 5.2 Luas luka B pada perawatan minggu 5

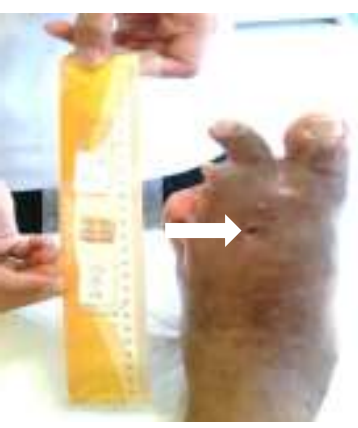

Gambar 5.4 Luas luka D pada perawatan minggu 5

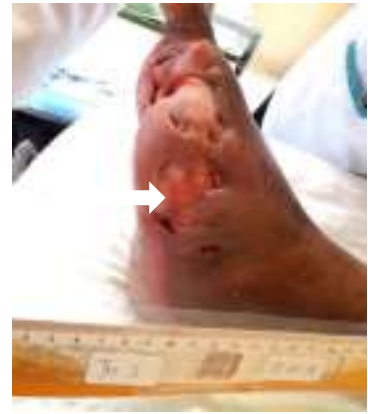

Gambar 5.6 Luas luka $F$ pada perawatan minggu 5

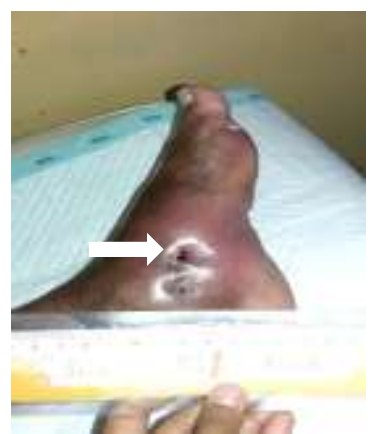

Gambar $\quad 5.7$ Luas luka $\mathrm{G}$ pada perawatan minggu 5

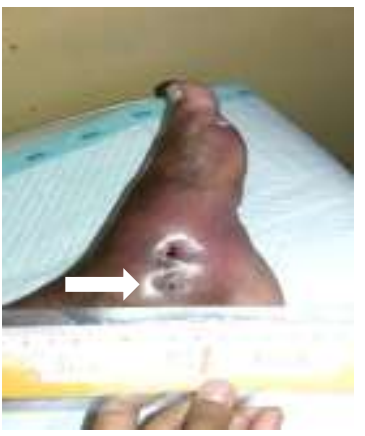

Gambar 5.8 Luas luka $\mathrm{H}$ pada perawatan minggu 5

\section{PEMBAHASAN}

Proses perawatan luka perlu dilakukan pemilihan dressing yang tepat. Pada kasus ini, dressing yang digunakan yaitu modern dressing. Metode perawatan luka yang berkembang saat ini menggunakan prinsip moisture balance yang dikenal sebagai modern wound dressing, dinyatakan lebih efektif dalam penyembuhan luka (Kartika, 2015). Modern wound dressing merupakan salah satu metode perawatan luka dengan cara tertutup dan lembab yang difokuskan untuk menjaga luka dari dehidrasi dan meningkatkan proses penyembuhan luka (Dhivya, Padma, \& Santhini, 2015). Modern wound dressing yang mengandung antimikroba telah dikembangkan sejak 20 tahun terakhir, efektif membunuh bakteri dan jamur pada luka, mencegah infeksi berulang selama penyembuhan (Boateng \& Catanzano, 2015). Penggunaan antimikroba yang telah digabungkan ke dalam modern wound dressing dapat memberikan efek yang baik terhadap proses penyembuhan luka. Karena, Antimikroba yang ada pada balutan luka dapat membunuh bakteri yang ada pada luka (Darwis, Basyir, Hardiningsih, \& Chosdu, 2013).

Pada kasus Tn. S, balutan yang digunakan yaitu pada balutan primer menggunakan hydrophobic (Cutimed ${ }^{\circledR}$ 
Sorbact ${ }^{\circledR}, \quad B S N$ Medical Ltd) serta diaplikasikan dengan salep yang mengandung zink, balutan sekunder menggunakan kasa steril dan diaper, dan balutan tersier menggunakan kasa gulung. Sedangkan perawatan tepi luka menggunakan salep zink. Cutimed sorbact merupakan dressing yang dilapisi dengan DiAlkyl Carbamoyl Chloride (DACC) merupakan turunan asam lemak yang sangat hidrofobik. Hidrofobik menarik bakteri dan mengikatnya secara irreversibel. Sehingga mampu menurunkan jumlah bakteri pada luka. Karena mekanismenya adalah pengikatan dan menghilangkan bakteri, maka tidak ada risiko bakteri menjadi resisten dan kurangnya bakteriolisis mencegah pelepasan endotoksin ke dasar luka (Totty, Smith, Bua, \& Harwood, 2017). Dipadukan dengan salep zink agar luka menjadi lembab karena lingkungan luka yang lembab juga memfasilitasi pergerakan bakteri ke dalam hidforofobik. Untuk adsorbent digunakan kasa dan diaper. Penggunaan diaper memungkinkan biaya perawatan yang lebih relatif terjangkau dan mampu menyerap eksudat.

Teknik debridemen yang digunakan pada kasus Tn. S yaitu Conservatif Sharp Wound Debridement (CSWD) dan autolysis untuk mengangkat slough yang mengeras. Assadian, et al. (2018) menyatakan bahwa langkah yang paling efektif digunakan dari wound bed preparation (WBD) adalah sharp mekanikal debridemen, diikuti oleh metode lain termasuk autolitik, enzimatik, biologis (larval debridement), atau debridement basah ke kering. Selain debridemen, metode wet to dry dari pembersihan luka (atau lebih tepatnya, teknik basah ke lembab) juga telah dijelaskan, yang tidak boleh disamakan dengan metode debridemen basah ke kering.

Perkembangan luka Tn. S dari minggu pertama hingga minggu kelima, terjadi perubahan jumlah eksudat dari sedang menjadi sedikit. Maserasi masih nampak pada luka Tn. S khusunya di bagian plantar (Luka A) dan hal ini bisa memperlambat proses penyembuhan. (Haryanto, et al., 2016) mengatakan bahwa ada hubungan antara maserasi dan area luka. Luka yang tidak mengalami maserasi lebih cepat sembuh dari pada luka maserasi. Maserasi dapat menunda penyembuhan dan memperbesar area luka. Selain itu, luka dengan maserasi lebih lemah dari luka yang tidak maserasi, dan mereka bisa menjadi rusak oleh trauma fisik dan terkikis oleh enzim proteolitik. Luka B menunjukkan progress yang baik dimana pada minggu keempat yaitu pertemuan ke-7 undermining pada luka menutup. Luka $\mathrm{C}$ juga menujukkan progress yang baik dimana pada pertemuan ke-8 telah epitelisasi $100 \%$ Luka D menunjukkan ukuran panjang dan kedalaman masing-masing bertambah pada pertemuan ke-8 yang diakibatkan oleh proses CSWD. Luka E menunjukkan progress yang baik dimana mengalami pengecilan ukuran dan kedalaman undermining. Luka $F$ juga menunjukkan peningkatan epitelisasi yang baik. Luka G mengalami pengecilan ukuran dan kedalaman undermining, dan luka $\mathrm{H}$ menunjukkan progress yang kurang baik karena pada pertemuan ke-3, 4, dan 5 luka telah berada pada fase poliferasi, namun kembali pada fase inflamasi pada pertemuan ke- 6 hingga ke- 8

Pada minggu pertama dan kedua, luka Tn. S berada pada fase inflamasi (peradangan). Karakteristik dari fase inflamasi adalah sakit, panas, kemerahan, dan bengkak. Tujuan utama fase inflamasi adalah untuk menghilangkan debris patogen. Pada minggu ketiga hingga kelima, luka Tn. $\mathrm{S}$ mengalami fase poliferasi. Tujuan dari fase ini adalah untuk mengisi luka 
dengan jaringan yang baru (Jaringan granulasi) dan memperbaiki integritas kulit. Fase ini biasanya berlangsung beberapa minggu (sekitar 3 minggu), tepi-tepi luka akan saling menarik (kontraksi), sehingga ukuran luka menjadi kecil. Fase terakhir dalam proses poliferasi adalah epitelisasi. Luka Tn. S diprediksi akan menutup pada minggu perawatan keenam, fase ini disebut fase maturasi atau remodelling yang berlangsung sekitar 3 minggu setelah injuri sampai beberapa bulan atau tahun. Fase ini melibatkan keseimbangan antara sintesis kolagen dan degradasinya dan serat kolagen mengalami maturasi (Sari, 2015). Luka pada kaki Tn. S tidak berpotensi amputasi jika proses perawatan luka tetap diimbangi dengan pemilihan dressing yang tepat dan kepatuhan pasien dalam menjalankan perawatan luka. Hal ini ditandai dengan tidak terdapatnya luka nekrotik selama 5 minggu perawatan.

Beberapa luka pada kasus Tn. S mengalami proses granulasi dan epitelisasi yang baik pada minggu terakhir perawatan. Namun, proses penyembuhan luka berjalan dengan lambat yang bisa disebabkan oleh beberapa faktor. Tn. S mengatakan bahwa dirinya cemas akan kondisinya dan malas makan. Jaffe \& Wu (2017) dalam penelitiannya mengatakan bahwa penyembuhan luka yang kompleks berkembang dari hemostasis, peradangan, proliferasi, dan remodeling jaringan secara tepat waktu. di antara faktor-faktor lain, proses ini bergantung pada tingkat nutrisi makro dan mikro yang memadai untuk memastikan perkembangan yang tepat melalui tahap-tahap ini. Pasien yang kekurangan gizi mungkin tidak memiliki gizi yang cukup untuk meningkatkan regenerasi jaringan yang menyebabkan luka menjadi kronik. Pasien mungkin kurang gizi karena sejumlah alasan, termasuk sumber daya keuangan yang terbatas, kurangnya dukungan keluarga, pembatasan diet, kecemasan, depresi, dan berkurangnya nafsu makan. Kecemasan dan kurangnya nafsu makan pada Tn. S juga mempengaruhi proses penyembuhan luka.

Pada kaki Tn. S pada kaki kiri maupun kanan juga mengalami edema sehingga disarankan untuk melakukan pemeriksaan darah untuk mengecek albumin dan mengontrol gula darahnya. Penelitian yang dilakukan oleh Edakkepuram, Sheeja, \& Gopi, (2017) menunjukkan bahwa hipoalbuminemia merupakan faktor utama dalam penyembuhan luka. Kontrol glikemik yang buruk juga merupakan faktor risiko penyembuhan luka di kaki diabetes.

Penyakit ginjal (nefropati diabetik) jauh lebih umum pada orang dengan diabetes dibandingkan pada orang tanpa diabetes. Hal ini disebabkan oleh kerusakan pembuluh darah kecil, yang dapat menyebabkan ginjal menjadi kurang efisien, atau gagal sama sekali. Diabetes adalah salah satu penyebab utama penyakit ginjal kronis. Mempertahankan kadar glukosa darah dan tekanan darah yang mendekati normal dapat sangat mengurangi risiko penyakit ginjal. Skrining untuk jumlah albumin yang tidak normal dalam urin (albuminuria) dan memulai pengobatan dengan obat yang mengurangi aktivitas sistem renin-angiotensin-aldosteron ketika albuminuria ditemukan secara persisten, bahkan tanpa adanya hipertensi, sangat efektif untuk mencegah perkembangan penyakit ginjal kronis pada penderita diabetes (IDF, 2017).

Ada beberapa keterbatasan pada penelitian ini. Pertama, responden penelitian ini hanya satu orang sehingga tidak dapat mewakili populasi penderita luka kaki diabetik. Kedua, partisipan peneliti lebih dari satu orang sehingga hasil pengkajian dari setiap 
partisipan peneliti menjadi bias karena pengkajian luka bersifat subjektif.

\section{KESIMPULAN}

Berdasarkan proses perawatan yang telah dilakukan selama 5 minggu pada kasus luka kaki diabetik Tn. S, dapat disimpulkan bahwa proses penyembuhan luka dalam 5 minggu perawatan berjalan sesuai fisiologi penyembuhan luka.

Pada minggu pertama dan kedua mengalami fase inflamasi, pada minggu ketiga hingga kelima mengalami proses poliferasi. Namun, waktu proses penyembuhan luka berjalan lambat. Luka pada kaki Tn. S diprediksi akan menutup pada minggu perawatan keenam, fase ini disebut fase maturasi atau remodelling. Terjadi perubahan ukuran dan kedalaman yang berbedabeda pada beberapa luka di setiap minggu perawatan. Luka pada kaki Tn. $\mathrm{S}$ tidak berpotensi amputasi jika proses perawatan luka tetap diimbangi dengan pemilihan dressing yang tepat dan kepatuhan pasien dalam menjalankan perawatan luka. Hal ini ditandai dengan tidak terdapatnya luka nekrotik selama 5 minggu perawatan. Tandatanda infeksi lokal pada luka Tn. S semakin berkurang di setiap minggu perawatan. Faktor-faktor lain yang menghambat proses penyembuhan luka juga perlu diketahui demi menunjang proses penyembuhan luka.

\section{DAFTAR PUSTAKA}

American Diabetes Association. (2018, January). Microvascular Complications and Foot Care: Standars of Medical Care in Diabetes. The Journal of Clinical and Applied Research and Education, 41(1), S105-S118. Retrieved from http://www.Diabetes.org/diabetescare

Ardi, M., Damayanti, S., \& Sudirman, S. (2014). Hubungan Kepatuhan Perawatan Kaki dengan Resiko Ulkus Kaki Diabetes di Poliklinik DM RSU Andi Makassau Pare. Jurnal Ilmiah Kesehatan Diagnosis, 4(1), 104-107. Retrieved from http://ejournal.stikesnh.ac.id/index.php/ jikd/article/download/632/507/

Assadian, O., Kammerlander, G., Geyrhofer, C., Luch, G., Doppler, S., Tuchmann, F., Eberlein, T., et al. (2018). Use of wet-tomoist cleansing with different irrigation solutions to reduce bacterial bioburden in chronic wounds. Journal of Wound Care, 27(10), S10-S16. doi:10.12968/jowc.2018.27.Sup10.S10

Boateng, J., \& Catanzano, O. (2015). Advanced Therapeutic Dressings for Effective Wound Healing- A Review. Journal of Pharmaceutical Sciences, 104(11), 36533680. doi: $10.002 /$ jps. 24610

Darwis, D., Basyir, T. E., Hardiningsih, L., \& Chosdu, R. (2013). Uji Daya antimikroba dan Sifat Fisiko-kimia Pembalut Luka Hidrogel Steril Radiasi yang Mengandung Ekstrak Buah Mengkudu (Morinda citrifolia L). Jurnal Ilmiah Aplikasi Isotop dan Radiasi, 1(1).

Dhivya, S., Padma, V. V., \& Santhini, E. (2015). Wound Dressing: A Review. Biomedicine. doi:10.7603/s40681-015-0022-9

Edakkepuram, U., Sheeja, P. C., \& Gopi, E. V. (2017). A Prospective Cohort Study of Hypoalbuminemia as Risk Factor of Wound Healing in Diabetic Foot: a study from tertiary hospital in South India. International Surgery Journal, 4(9), 31413145. doi:10.18203/23492902.isj20173903

Haryanto, H., Arisandi, D., Suriadi, S., Imran, I., Ogai, K., Sanada, H., Okuwa, M., et al. (2016). Relationship between maceration and wound healing on diabetic foot ulcers in Indonesia: a prospective study. International Wound Journal, 1-7. doi:10.1111/iwj.12638

International Diabetes Federation. (2017). IDF Diabetes Atlas (8th ed.). Brussels: International Diabetes Federation. Retrieved from http://diabetesatlas.org/ resources/2017-atlas.html

Jaffe, L., \& Wu, S. (2017). Th Role of Nutrition in Chronic Wound Care Management: What patients eat affects how they heal. Retrieved from The Diabetic Foot: http://podiatrym.com/pdf/2017/11/Jaffe Wu1117web.pdf

Kartika, R. W. (2015). Perawatan Luka Kronis dengan Modern Dressing. Jurnal Keperawatan Akper Pemkab Purworejo, 42(7), 546-550. Retrieved from http://journal.akperkabpurworejo.ac.id/i ndex.php/luka/issue/view/1/Modern\%20 Dressing

Perkumpulan Endokrinologi Indonesia. (2015). Konsensus Pengelolaan dan Pencegahan 
Diabetes Melitus Tipe 2 di Indonesia. Jakarta: PB PERKENI.

Sari, Y. (2015). Perawatan Luka Diabetes. Yogyakarta: Graha Ilmu.

Totty, J., Smith, G. E., Bua, N., \& Harwood, A. E. (2017). Dialkylcarbamoyl chloride (DACC)-coated dressings in the management and prevention of wound infection: a systemic review. Journal Wound Care, 26(3), 107-114. doi:194.176.105.154

World Health Organization. (2016). Global Report on Diabetes. Geneva: WHO Press. Retrieved Oktober 25, 2018, from World Health Organization. 